\title{
SIFAT ORGANOLEPTIK NUGGET DAGING BROILER MENGGUNAKAN TEPUNG TEMPE
}

\author{
Ermila Nile, I. Wahyuni*, T. A. Ransaleleh, L. Ch. M. Karisoh \\ Fakultas Peternakan Universitas Sam Ratulangi Manado, 95115
}

\begin{abstract}
ABSTRAK
Tujuan penelitian ini untuk mengetahui sifat organoleptik nugget daging broiler menggunakan tepung tempe. Penelitian ini menggunakan Rancangan Acak Lengkap (RAL) dan pengukuran data organoleptik menggunakan skala hedonik dengan 40 panelis dan 4 perlakuan yang terdiri dari $\mathrm{R} 0=$ daging broiler 300 gram tanpa tepung tempe, R1 = daging broiler 300 gram ditambah $10 \%$ tepung tempe, R2 = daging broiler 300 gram ditambah $20 \%$ tepung tempe, R3 = daging broiler 300 gram ditambah $30 \%$ tepung tempe. Variabel yang diamati yaitu warna, aroma, tekstur, keempukan dan citarasa. Hasil sidik ragam menunjukkan bahwa perlakuan memberikan pengaruh sangat nyata $(\mathrm{P}<0,01)$ terhadap warna dan citarasa nugget, dan memberikan pengaruh nyata $(\mathrm{P}<0,05)$ terhadap keempukan nugget tetapi untuk aroma dan tekstur nugget tidak memberikan pengaruh yang nyata $(\mathrm{P}>0,05)$. Berdasarkan hasil analisa data dan pembahasan maka disimpulkan bahwa sifat organoleptik nugget daging broiler menggunakan tepung tempe sampai dua puluh persen disukai oleh panelis.
\end{abstract}

Kata kunci : Organoleptik, Tepung Tempe, Nugget

*Korespondensi (corresponding author) Email: indiyah_unsrat@yahoo.com

\section{ABSTRACT}

ORGANOLEPTIC CHARACTERISTICS OF CHICKEN NUGGET USING TEMPE FLOUR. The purpose of this research was to determine the organoleptic characteristics of chicken nuggets using tempe (fermented soybean) flour. This research was using Completely Randomized Design (CRD) and hedonic scale with 40 panelists and 4 treatments as follows, $\mathrm{R} 0=300$ grams chicken meat without tempe flour, R1 $=300$ grams chicken meat added with $10 \%$ tempe flour, $\mathrm{R} 2=300$ grams chicken meat added with $20 \%$ tempe flour, $\mathrm{R} 3=300$ grams chicken meat added with $30 \%$ tempe flour. The variables observed in this study were including color, flavor, texture, tenderness and taste. The results showed that the treatments affected significantly the color, taste and tenderness of chicken nuggets, but did not affect the flavor and texture of chicken nuggets. Therefore, it can be concluded that organoleptic characteristics of chicken nugget using tempe flour up to twenty percent were preferred by panelists.

Key words : Organoleptic, Tempe Flour, Chicken Nugget

\section{PENDAHULUAN}

Perubahan gaya hidup sering menjadi faktor terjadinya perubahan pola konsumsi. Dengan bertambahnya waktu 
bekerja, masyarakat semakin sibuk sehingga mendorong pemilihan makanan dengan penyajian yang lebih praktis tetapi beragam, bergizi dan aman. Daging broiler menjadi bahan utama dalam pembuatan nugget karena memiliki citarasa yang enak dan kandungan gizinya yang lengkap. Masyarakat mengenal dua bentuk produk daging broiler yang dimanfaatkan sebagai sumber protein hewani yaitu daging segar dan daging olahan. Pada umumnya pengolahan dilakukan bertujuan untuk mempertahankan daya simpan suatu produk bahan pangan yang mudah mengalami kerusakan, untuk memberikan nilai tambah, cita rasa dan meningkatkan kualitas produk itu sendiri.

Nugget merupakan makanan siap saji dari produk daging giling yang dibumbui, dicetak, dimasak kemudian diselimuti oleh perekat tepung (batter), pelumuran tepung roti (breading), lalu dibekukan, kemudian digoreng. Lama penggorengan hanya membutuhkan waktu 1 sampai 4 menit. Selain diberi bahan pelapis, ada juga bahan pengikat dan bahan pengisi. Tepung tempe mudah dicerna dan diserap oleh tubuh, kandungan proteinnya tinggi, kandungan gizi senyawa organiknya lengkap dan bermanfaat bagi kesehatan. Oleh karena itu, tepung tempe digunakan sebagai bahan pengisi dan bahan pengikat pada pembuatan nugget daging broiler.
Tepung tempe dibuat dari bahan dasar tempe, sebagai upaya untuk meningkatkan daya simpan tempe maka diolah menjadi tepung tempe. Untuk mengetahui tingkat kesukaan konsumen terhadap nugget daging broiler menggunakan tepung tempe maka perlu adanya uji sifat organoleptik. Uji sifat organoleptik meliputi warna, aroma, tekstur, keempukan dan citarasa. Hasil penelitian Afrisanti (2010), penggunaan tepung tempe pada level tertentu memberikan pengaruh nyata terhadap penilaian warna, aroma, tekstur, keempukan dan citarasa nugget daging kelinci. Berdasarkan uraian diatas, telah dilakukan penelitian yang bertujuan untuk mengetahui tingkat penerimaan panelis pada nugget daging broiler yang menggunakan tepung tempe.

\section{MATERI DAN METODE PENELITIAN}

Penelitian ini telah dilaksanakan pada tanggal 16 November sampai tanggal 06 Desember 2016 di Laboratorium Teknologi Hasil Ternak Fakultas Peternakan Universitas Sam Ratulangi Manado. Bahan yang digunakan dalam penelitian ini adalah daging broiler bagian dada sebanyak 1200 gram, tepung tempe 
sebanyak 180 gram, tepung tapioka 60 gram, tepung roti, tepung panir, susu bubuk 40 gram, es batu 65 gram, kuning telur 3 butir, garam 3 gram, bawang putih 10 gram, bawang merah 10 gram, royco 10 gram, lada 2 gram, minyak goreng, mentimun dan aqua. Peralatan yang digunakan adalah cooper, termometer, timbangan, freezer, blender, water bath, kompor gas, alat penggoreng, mangkuk, piring, pisau, talenan, plastik, aluminium foil, loyang aluminium, baskom, format uji, alat tulis menulis dan peralatan masak lainnya.

Metode penelitian yang digunakan adalah Rancangan Acak Lengkap (RAL), yang terdiri atas 4 perlakuan, yaitu :

$\mathrm{R} 0=$ Daging broiler 300 gram tanpa tepung tempe

$\mathrm{R} 1=$ Daging broiler 300 gram ditambah $10 \%$ tepung tempe
R2 = Daging broiler 300 gram ditambah $20 \%$ tepung tempe

R3 = Daging broiler 300 gram ditambah $30 \%$ tepung tempe

Variabel yang diamati adalah warna, aroma, tekstur, keempukan dan citarasa, menggunakan skala hedonik dengan 40 panelis tidak terlatih (Suradi, 2007). Data yang diperoleh dianalisis dengan analisis keragaman (Analysis of Variance), dan yang berbeda nyata diuji lanjut dengan menggunakan Uji Wilayah Berganda Duncan (Steel and Torrie, 1991).

\section{HASIL DAN PEMBAHASAN}

Data hasil analisis nilai rataan pengaruh penggunaan tepung tempe terhadap mutu organoleptik nugget daging broiler dapat di lihat pada Tabel 1.

Tabel 1. Nilai Rataan Penggunaan Tepung Tempe Terhadap Sifat Organoleptik Nugget Daging Broiler.

\begin{tabular}{lcccc}
\hline \multirow{2}{*}{ Variabel } & \multicolumn{4}{c}{ Persentase Tepung Tempe } \\
\cline { 2 - 5 } & $\mathrm{R} 0$ & $\mathrm{R} 1$ & $\mathrm{R} 2$ & $\mathrm{R} 3$ \\
& $0 \%$ & $10 \%$ & $20 \%$ & $30 \%$ \\
\hline Warna & $5,80^{\mathrm{ab}}$ & $5,98^{\mathrm{a}}$ & $5,52^{\mathrm{bc}}$ & $5,20^{\mathrm{c}}$ \\
Aroma & 5,60 & 5,88 & 5,58 & 5,53 \\
Tekstur & 5,35 & 5,48 & 5,45 & 5,30 \\
Keempukan & $5,75^{\mathrm{a}}$ & $5,63^{\mathrm{ab}}$ & $5,25^{\mathrm{abc}}$ & $5,07^{\mathrm{c}}$ \\
Citarasa & $5,45^{\mathrm{ab}}$ & $6,05^{\mathrm{a}}$ & $5,58^{\mathrm{ab}}$ & $4,83^{\mathrm{c}}$ \\
\hline
\end{tabular}

Keterangan : Superskrip yang berbeda pada kolom yang sama artinya berbeda nyata $(\mathrm{P}<0,05)$ 


\section{Warna Nugget}

Nilai rataan warna nugget daging broiler dengan penggunaan tepung tempe dapat dilihat pada Tabel 3. Data tersebut menunjukkan bahwa nilai rataan tingkat kesukaan panelis terhadap warna nugget berkisar dari 5,20 (agak suka) sampai 5,98 (suka). Hasil sidik ragam menunjukkan bahwa penggunaan tepung tempe pada nugget daging broiler memberikan pengaruh sangat nyata $(\mathrm{P}<0,01)$ terhadap warna nugget.

Hasil uji lanjut Duncan menunjukkan bahwa warna nugget pada perlakuan tanpa tepung tempe tidak berbeda nyata dengan perlakuan persentase tepung tempe $10 \%$ dan $20 \%$ tetapi berbeda nyata dengan perlakuan persentase tepung tempe $30 \%$. Perlakuan persentase tepung tempe $10 \%$ berbeda nyata dengan perlakuan persentase tepung tempe $20 \%$ dan 30\%. Perlakuan persentase tepung tempe $20 \%$ tidak berbeda nyata dengan perlakuan persentase tepung tempe $30 \%$. Perlakuan persentase tepung tempe $30 \%$ tidak berbeda nyata dengan perlakuan persentase tepung tempe $20 \%$ tetapi berbeda nyata dengan perlakuan persentase tepung tempe $10 \%$ dan perlakuan tanpa tepung tempe. Artinya, panelis lebih menyukai warna nugget yang kuning keemasan dibandingkan warna nugget yang kecokelatan, karena semakin meningkat persentase tepung tempe warna nugget akan semakin cokelat.

Tepung tempe yang juga tinggi kandungan proteinnya menyebabkan terjadinya reaksi pencokelatan (reaksi maillard) pada saat penggorengan. Rusdin (2015), menyatakan bahwa reaksi maillard merupakan reaksi kompleks yang melibatkan gula reduksi dan gugus amin dari protein pada saat penggorengan, menghasilkan senyawa baru yang berwarna cokelat yaitu melanoidin. Hal ini sesuai dengan hasil penelitian Heridiansyah et al. (2014), adanya perbedaan warna pada nugget tempe akibat terjadinya reaksi maillard (reaksi non enzimatis) yaitu reaksi antara karbohidrat (gula sederhana) dengan protein (gugus amino), yang menyebabkan warna nugget menjadi kecokelatan.

\section{Aroma Nugget}

Nilai rataan aroma nugget daging broiler dengan penggunaan tepung tempe dapat dilihat pada Tabel 3. Data tersebut menunjukkan bahwa nilai rataan tingkat kesukaan panelis terhadap aroma nugget berkisar dari 5,53 sampai 5,88 (suka). Hasil sidik ragam menunjukkan bahwa penggunaan tepung tempe pada nugget daging broiler memberikan pengaruh tidak nyata $(\mathrm{P}>0,05)$ terhadap aroma nugget.

Panelis menyukai aroma nugget dari perlakuan tanpa tepung tempe sampai pada perlakuan persentase tepung tempe 
30\%. Namun, ada kecenderungan tingkat kesukaan panelis menurun seiring dengan meningkatnya persentase tepung tempe. Hal ini karena aroma khas nugget daging broiler berkurang dengan semakin meningkatnya persentase tepung tempe, karena adanya bau langu pada tepung tempe. Kurniawati dan Fitriyono (2012), menyatakan bahwa bau langu pada tepung tempe disebabkan oleh aktivitas enzim lipoksigenase yang secara alami ada dalam biji kedelai. Berdasarkan hasil penelitian Permatasari dan Arintina (2013), enzim lipoksigenase bereaksi dengan lemak dan menghasilkan suatu senyawa organik yaitu etil fenil keton penyebab bau langu.

\section{Tekstur Nugget}

Nilai rataan tekstur nugget daging broiler dengan penggunaan tepung tempe dapat dilihat pada Tabel 3. Data tersebut menunjukkan bahwa nilai rataan tingkat kesukaan panelis terhadap tekstur nugget berkisar dari 5,30 sampai 5,48 (agak suka). Hasil sidik ragam menunjukkan bahwa penggunaan tepung tempe pada nugget daging broiler memberikan pengaruh tidak nyata $(\mathrm{P}>0,05)$ terhadap tekstur nugget.

Hal ini menunjukkan bahwa persentase level tepung tempe yang berbeda memiliki pengaruh yang sama terhadap tekstur nugget yang dihasilkan. Namun, semakin meningkat persentase tepung tempe tingkat kesukaan panelis cenderung menurun karena tekstur nugget semakin padat. Hal ini sesuai dengan hasil penelitian Aini et al. (2010), semakin banyak persentase tepung tempe maka akan menghasilkan tekstur yang lebih padat.

\section{Keempukan Nugget}

Nilai rataan keempukan nugget daging broiler dengan penggunaan tepung tempe dapat dilihat pada Tabel 3. Data tersebut menunjukkan bahwa nilai rataan tingkat kesukaan panelis terhadap keempukan nugget berkisar dari 5,07 (agak suka) sampai 5,75 (suka). Hasil sidik ragam menunjukkan bahwa penggunaan tepung tempe pada nugget daging broiler memberikan pengaruh nyata $(\mathrm{P}<0,05)$ terhadap keempukan nugget.

Hasil uji lanjut Duncan menunjukkan bahwa perlakuan persentase tanpa tepung tempe tidak berbeda nyata dengan perlakuan persentase tepung tempe $10 \%$ dan $20 \%$, tetapi berbeda nyata dengan perlakuan persentase tepung tempe $30 \%$. Perlakuan persentase tepung tempe $10 \%$ tidak berbeda nyata dengan perlakuan persentase tepung tempe $20 \%$ tetapi berbeda nyata dengan perlakuan persentase tepung tempe $30 \%$. Perlakuan persentase tepung tempe $20 \%$ tidak berbeda nyata dengan perlakuan persentase tepung tempe $30 \%$. Perlakuan persentase tepung tempe $30 \%$ tidak berbeda nyata dengan perlakuan persentase tepung tempe $20 \%$ tetapi 
berbeda nyata dengan perlakuan persentase tepung tempe $10 \%$ dan perlakuan tanpa tepung tempe. Perbedaan tersebut disebabkan oleh penurunan kualitas keempukan nugget dengan semakin bertambahnya persentase tepung tempe.

Hal ini karena tepung tempe banyak mengandung protein (Kurniawati dan Fitriyono, 2012) dan bersifat hidroskopis atau mengikat air (Aini et al., 2010), sehingga semakin tinggi persentase level tepung tempe akan menyebabkan tingkat keempukan nugget menurun atau semakin tidak empuk. Bila dibandingkan dengan penelitian Afrisanti (2010), tentang nugget kelinci hasil yang didapat dengan penelitian ini relatif sama sampai level 20\% masih menunjukkan kategori empuk dan pada level 25\% nugget dalam kategori kurang empuk, hal ini disebabkan karena persentase level tepung tempe yang semakin meningkat.

\section{Citarasa Nugget}

Nilai rataan citarasa nugget daging broiler dengan penggunaan tepung tempe dapat dilihat pada Tabel 3. Data tersebut menunjukkan bahwa nilai rataan tingkat kesukaan panelis terhadap citarasa nugget berkisar dari 4,83 (agak suka) sampai 6,05 (suka). Hasil sidik ragam menunjukkan bahwa penggunaan tepung tempe pada nugget daging broiler memberikan pengaruh sangat nyata $(\mathrm{P}<0,01)$ terhadap citarasa nugget.

Hasil uji lanjut Duncan menunjukkan bahwa pada perlakuan tanpa tepung tempe tidak berbeda nyata dengan perlakuan persentase tepung tempe $10 \%$ dan $20 \%$ tetapi berbeda nyata dengan perlakuan persentase tepung tempe $30 \%$. Perlakuan persentase tepung tempe $10 \%$ tidak berbeda nyata dengan perlakuan persentase tepung tempe $20 \%$ tetapi berbeda nyata dengan perlakuan persentase tepung tempe $30 \%$. Perlakuan persentase tepung tempe $20 \%$ berbeda nyata dengan perlakuan persentase tepung tempe $30 \%$. Perlakuan persentase tepung tempe $30 \%$ berbeda nyata dengan perlakuan persentase tepung 20\%, 10\% dan perlakuan tanpa tepung tempe.

Perbedaan tersebut disebabkan oleh penurunan nilai citarasa yang menunjukkan penurunan kualitas organoleptik. Penurunan kualitas organoleptik karena meningkatnya persentase tepung tempe pada nugget menyebabkan citarasa menjadi kurang enak. Aini et al., (2010), menyatakan bahwa menurunnya tingkat kesukaan panelis terhadap citarasa nugget karena rasa langu khas tempe meningkat seiring dengan bertambahnya persentase tepung tempe. Pada hasil uji citarasa juga didapatkan hasil yang tidak berbeda nyata yaitu pada perlakuan tanpa tepung tempe, persentase tepung tempe $10 \%$ dan $20 \%$. 
Berdasarkan hasil penelitian Afrisanti (2010), hal ini dipengaruhi oleh hasil uji lainnya (aroma, tekstur, keempukan), sesuai dengan pendapat Winarno (1997), citarasa adalah rangsangan syaraf yang dihasilkan oleh bahan yang dimasukan kedalam mulut, dirasakan terutama oleh syaraf bau, rasa dan rangsangan mulut.

\section{KESIMPULAN}

Berdasarkan hasil analisa data dan pembahasan maka disimpulkan bahwa sifat organoleptik nugget daging broiler dengan penggunaan tepung tempe sampai dua puluh persen disukai oleh panelis.

\section{DAFTAR PUSTAKA}

Afrisanti, D.W. 2010. Kualitas Kimia dan Organoleptik Nugget Daging Kelinci dengan Penambahan Tepung Tempe. Skripsi. Program Studi Peternakan. Fakultas Pertanian Universitas Sebelas Maret Surakarta

Aini, N., V. Prihananto dan S. Joni Munarso. 2010. Pengaruh perendaman jagung dan substitusi tepung tempe terhadap nilai gizi dan sifat sensoris beras jagung instan. Jurnal Agrotek 5(2): 71-82.

Heridiansyah, N., H. Nur'aini dan Darius. 2014. Pengaruh jenis tempe dan bahan pengikat terhadap karakteristik nugget tempe. Jurnal Agribisnis Teknologi Pangan, 1(1): 109-118.

Kurniawati dan A. Fitriyono. 2012. Pengaruh subtitusi tepung terigu dengan tepung tempe dan tepung ubi jalar kuning terhadap kadar protein, $\beta$-karoten, dan mutu organoleptik roti manis. Journal of Nutrition College 1(1): 344-351.

Permatasaari, P. K. dan R. Arintina 2013. Nugget tempe dengan substitusi ikan mujair sebagai alternatif makanan sumber protein, serat, dan rendah lemak. Journal of Nutrition College, 2 (1) : 1-9.

Rusdin, R. 2015. Kimia Pangan. Perpustakaan Nasional, Yogyakarta.

Steel, R. G. D. and J. H. Torrie. 1991. Prinsip dan Prosedur Statistika, Suatu Pendekatan Biometrik. PT Gramedia Pustaka Utama. Jakarta.

Suradi, K. 2007. Tingkat kesukaan bakso dari berbagai jenis daging melalui beberapa pendekatan statistik. Jurnal Ilmu Ternak 7(1) : 52-57.

Winarno, F.G. 1977. Kimia Pangan dan Gizi. PT. Gramedia Pustaka Utama, Jakarta 